\author{
ALEKSANDRA JASIELSKA \\ Uniwersytet Adama Mickiewicza, Poznań
}

\title{
PROTOTYPOWY OBRAZ POGARDY W NARRACJACH POTOCZNYCH
}

Słowa kluczowe: reprezentacja emocji, narracyjny model emocji, pogarda, triada wrogości, retoryka nienawiści.

\section{STRESZCZENIE}

Badanie opisane w artykule opiera się na założeniu, że wiedza o emocjach jest zorganizowana w postaci prototypów i narracji. Przedmiotem badania o charakterze eksploracyjnym jest społeczna emocja złożona - pogarda. Uczestnicy badania $(\mathrm{N}=136)$ zostali poproszeni o opisanie autobiograficznego wspomnienia, podczas którego doświadczali pogardy. Uzyskane od badanych narracje zostały skategoryzowane przez sędziów kompetentnych. W rezultacie otrzymano prototypowy opis pogardy. Ponadto otrzymano wyniki dotyczące: (1) charakterystyki prototypu emocji złożonej, (2) analizy strukturalnej prototypu pogardy, (3) niespecyficznej „potencjalnej syntezy” w obszarze emocji postkognitywnych oraz (4) specyficznej triady wrogości.

Zażytość karmi pogardę i dzieci.

Mark Twain

\section{WPROWADZENIE}

Emocja jest afektywnym przeżyciem psychicznym i jest reprezentowana, tak jak inne zjawiska z rzeczywistości pozajęzykowej, w przestrzeni mentalnej w odmiennym niż macierzysty systemie znaków (Jasielska 2013: 13-23; Maruszewski, Ścigała 1998: 52-78; Nowakowska-Kempna, 2000: 87-90). Reprezentacja emocji uwzględnia procesy konceptualizacji, czyli poznawania rzeczywistości, związane z przetwarzaniem danych w systemie poznawczym oraz ich rejestrowaniem w pamięci trwałej i doświadczeniu. Inaczej rzecz ujmując, reprezentacja emocji będąc efektem procesów poznawczych jest uwewnętrznioną i zgeneralizowaną wiedzą na temat doświadczeń emocjonalnych jednostki, która przybiera postać pojęciową. Z kolei pojęcie zazwyczaj staje się ujęzykowione, w związku z czym znaczenie potoczne pojęcia oznacza to, co ludzie „myślą” lub „mają na myśli”, kiedy używają nazwy tego pojęcia (Wierzbicka 1999: 414). W literaturze przedmiotu istnieje stanowisko, zgodnie z którym potoczna reprezentacja emocji może przyjmować formę prototypu (Russell, Lemay 2005). Szereg badań pokazuje, że reprezentacje emocji nie posiadają charakterystyki pojęć klasycznych, 
ukonstytuowanych przez zbiór cech koniecznych i wystarczających, dzięki którym proces klasyfikacji ma charakter stabilny. Przeciwnie, pojęcia emocji mają rozmyte granice i charakterystykę probabilistyczną, przez co łatwiej dokonywać klasyfikacji i podawać przykłady egzemplarzy kategorii, niż określić zbiór cech definicyjnych. Podejście to jest nawiązaniem do koncepcji pojęć naturalnych Eleonory Rosch (2006) opartej na prototypach. Koncepcja ta mówi, że na każdym poziomie hierarchicznej organizacji pojęć można wskazać prototyp, czyli najczystszy przypadek przynależności kategorialnej. W tym podejściu klasyfikacja egzemplarzy do danej kategorii odbywa się poprzez porównanie danego egzemplarza do prototypu. Im dany egzemplarz jest bardziej podobny do prototypu, tym proces kategoryzacji zachodzi krócej. Z kolei gdy mamy do czynienia z egzemplarzem mało podobnym do prototypu, to kategoryzacja zachodzi dłużej, a sam egzemplarz uznawany jest za nietypowego reprezentanta danej kategorii. W badaniach udowodniono, że pojęcia zarówno emocji podstawowych (np. wstręt: Nabi 2002; złość: Russell, Fehr 1994; smutek, strach, radość: Shaver, Schwartz, Kirson, O’Connor 1987), jak i emocji złożonych (np. nienawiść, zazdrość: Fitness, Fletcher 1993; duma, wstyd: Fischer, Manstead, Mosquera 1999; poczucie winy: Lindsay-Hartz, deRivera, Mascolo 1995; zakłopotanie: Danieluk 2013) mają charakter prototypowy. Przykładowo okazało się, że prototypem emocji dla laików jest szczęście (Fehr, Russell 1984), a prototypem miłości miłość przyjacielska (Fehr 2007).

\section{FABULARNY MODEL ROZUMIENIA EMOCJI}

Istnieje bogaty zbiór modeli opisujących znaczenie emocji (Jasielska 2013: 36-56). Jednym $z$ nich jest model fabularny, w którym wiedza o emocjach przyjmuje formę schematycznego scenariusza zdarzenia. W scenariuszu tym pojawia się sytuacja wyzwalająca - przyczyna, która powoduje, że jednostka przeżywa emocję i wywołuje u osoby zmiany w zachowaniu. W sekwencji tej musi być obecna zasada scalająca poszczególne elementy w porządek o określonym znaczeniu. W przypadku pojęcia emocji spójność w obrębie danej kategorii może być pochodną np. relacji przyczynowej między cechami definiującymi pojęcie (Siemer 2008).

Jedną z podkategorii modelu fabularnego jest model schematu działań (ang. script-like event schemas, White 2005: 63). Zgodnie z jego założeniami wiedza o emocjach ma postać skryptopodobnego schematu zdarzenia złożonego z elementarnych subwydarzeń. Subwydarzenia tworzące schemat to takie elementy, jak: przyczyna, przekonania, doznania fizjologiczne, subiektywne odczucie, pragnienia, jawne zachowanie, ekspresja wokalna i mimiczna oraz próby kontroli (Kövecses 2000; Russell 1991). Uporządkowanie tych elementów ma charakter zarówno przyczynowo-skutkowy jak i temporalny. Wielokrotne przeżywanie określonych sytuacji prowadzi do połączenia scen w ogólniejszy wzorzec.

Do badania skryptów emocji rekomendowane są cztery specyficzne strategie empiryczne (Saarni 1999: 149-150). Są to: metoda obserwacyjna, metoda bezpośrednich próbek zachowania, metoda sprawozdania i metoda narracji. Ostatnia z metod na- 
wiązuje do drugiej podkategorii modelu fabularnego, a mianowicie narracyjnego modelu znaczenia emocji. Model ten koresponduje z rozumieniem emocji przez antropologów kulturowych, którzy definiują emocję jako kulturowo zdeterminowaną skryptopodobną narrację (inaczej uczuciowe opowiadanie) (Shweder 1998), która jest reprezentowana w przekazach kulturowych, takich jak np. kanoniczne teksty sanskryckie (Shweder, Haidt 2005), mity kulturowe (Pankalla, Grońska-Turunen 2010) czy dramaty (Hogan 2003).

Ujęcie psychologiczne modelu narracyjnego koncentruje się raczej na autonarracji, rozumianej, jako, ,[...] treść emocji i motywów jednostki kształtowana jest w toku interpretowania przez nią zdarzeń, w których uczestniczy, jako określonych historii" (Trzebiński 2002: 40). Wykorzystując do badania rozumienia emocji procedury narracyjne, zaobserwowano, że badani z dużą łatwością opisują sytuacje wywołujące emocje oraz rozbudowują te opisy o dodatkowe cechy charakterystyczne związane z danym przeżyciem emocjonalnym (Gawda 2007, 2011). Historia emocjonalna zawiera miejsce, czas, bohaterów, intencje, wydarzenia, role itd. Posiada także wyrazistą typową strukturę dramaturgiczną zawierającą odpowiednio „początki”, „sceny” i ,zakończenia” (Trzebiński 2002: 60). Kluczowym elementem narracji jest tzw. „narracyjna wątkowość" (ang. narrative emplotment), czyli przewidywalny kierunek rozwoju sytuacji, w której przeżywamy emocje (Saarni 1999).

Z punktu widzenia ustaleń językoznawczych narracja, w tym także narracja dotycząca emocji, jest zjawiskiem o podwójnej tożsamości. Wynika to z faktu, że narracja realizuje jednocześnie dwie podstawowe funkcje psychiczne języka — komunikacyjną i poznawczą (por. funkcje ekspresyjna i refencjalna, Nęcka, Orzechowski, Szymura 2006: 590-592), przez co może być ujmowana zarówno jako forma wypowiedzi, jak i reprezentowania emocji. Dodatkowo pochodną funkcji komunikacyjnej jest ekspresywna funkcja języka rozumiana jako, ,zdolność języka do powiadamiania odbiorcy o doznaniach uczuciowych nadawcy wypowiedzi, do informowania go o stanie emocjonalnym mówiącego" (Malczewski 1985: 52). Przy czym językowe komunikowanie emocji może mieć dwojaki charakter. Po pierwsze jednostka, przeżywając emocje, mówi z uczuciem, stosując wyrażenia i konstrukcje ekspresywne, oraz dodatkowo może przejawiać emocje poprzez środki tekstowe i parajęzykowe (Lewiński 2006: 51; Mikołajczuk 2006: 86). Po drugie jednostka mówi o uczuciach, czyli wolicjonalnie, wprost, pod asercją komunikuje i informuje o emocjach. W wypowiedziach tych charakterystyczne jest stosowanie nazw emocji, sfrazeologizowanych opisów uczuć, precyzyjnych rozróżnień stanów afektywnych oraz bogatego opisu, oddającego niuanse emocjonalne (Mikołajczuk 2006: 86). I to właśnie w tym obszarze mieści się narracja rozumiana jako zamierzony sposób opisywania przez nadawcę emocji swoich i/lub innych osób.

Z kolei dzięki funkcji poznawczej języka, czyli zdolności ,języka do odzwierciedlania w swojej strukturze i w zasobie słownictwa całej różnorodności zjawisk realnych, gromadzenia wiedzy o przedmiotach oraz łączących je zjawiskach” (Malczewski 1985: 53) i pochodnej wobec niej funkcji reprezentatywnej języka definiowanej, jako ,zdolność języka do zastępowania, czy symbolizowania zjawisk otaczającej nas rzeczywis- 
tości” (Malczewski 1985: 53), jednostka stabilizuje ,zmysłowo-afektywne” doznawanie emocji, dzięki czemu emocja może zaistnieć w przestrzeni mentalnej (Nowakowska-Kempna 2000: 87-88). Zatem to, co ludzie mówią o emocjach vel uczuciach, pokazuje, w jaki sposób rozumieją i konceptualizują emocje (Duszak 2003; Szumska 2000). W proces ten włączone są dwa rodzaje wiedzy. Jedna $\mathrm{z}$ nich to wiedza o emocjach obecna w reprezentacjach wyobrażeniowo-pojęciowych, która zgodnie z przyjętym w niniejszej publikacji założeniem może przybierać formę narracyjną. Druga to wiedza językowa niezbędna do wyrażania tych reprezentacji w języku (Kövecses 2000: 6; Marczewska-Okuniewska, Kurcz 2003). W związku z tym

badanie emocji sprowadza się do dwu podstawowych płaszczyzn poszukiwań: jak ludzie mówią o emocjach, a tym samym, co język emocji mówi nam o doświadczaniu i ludzkiej konceptualizacji emocji, oraz jak ludzie wyrażają emocje w działaniu językowym w różnych kontekstach sytuacyjnych, społecznych, a także kulturowych (Duszak 2003: 14).

Rekapitulując, przyjmuje się, że reprezentacja emocji jako trwała reprezentacja poznawcza (Nęcka, Orzechowski, Szymura 2006: 60) może być umysłowym scenariuszem bądź narracją. W oparciu o tę reprezentację jednostka konstruuje nietrwałą reprezentację słowną (Nęcka, Orzechowski, Szymura 2006: 62-63), pod postacią autonarracji. Wszystkie te trzy formy reprezentacji są strukturalnie podobne i w sytuacji badania wzajemnie na siebie nachodzą. Cechą, która różnicuje te stany, jest powszechność. Model skryptu koresponduje $\mathrm{z}$ jednostkowymi formami reprezentacji, podczas gdy model narracyjny aspiruje do reprezentacji uniwersalnej (por. opisany poniżej model dyskursywny rozumienia emocji).

\section{CHARAKTERYSTYKA POGARDY}

W literaturze przedmiotu pogarda jest zgodnie uznawana za emocję postkognitywną. I choć klasyczne badania wyrazów mimicznych emocji pokazały, że wyraz twarzy towarzyszący pogardzie jest identyfikowany przez różne kultury, co implikuje, że jest to emocja o charakterystyce emocji podstawowej (Ekman 1992), to sam autor badań wycofał się z takiej interpretacji. Jaak Panksepp (2005) jest przekonany, że pogarda należy do grona emocji wtórnych, inaczej złożonych, które są powszechne u ludzi, bo wynikają z ewolucyjnej ekspansji przodomózgowia. Pogarda jest emocją o niskiej częstotliwości w życiu codziennym (Wagner 2000). Ponadto jest wywoływana przez osobę lub grupę obcą (Rozin, Lowery, Imada, Haidt 1999), przez co uznawana jest za emocję społeczną (Fischer, Manstead 2008), choć istnieją ostatnie doniesienia z obszaru psychologii klinicznej, wskazujące na istnienie tzw. samopogardy (ang. self-contempt, Ben-Ze'ev 2000: 397). Wprawdzie nie podjęto jeszcze systematycznych badań nad tym zagadnieniem, ale istnieje przekonanie zgłaszane przez klinicystów, że samopogarda to emocja vel postawa, która towarzyszy zjawisku negacji siebie i towarzyszy zachowaniom związanym z samokaraniem. 
W aspekcie funkcjonalnym przyjmuje się, że pogarda wiąże się z traktowaniem drugiej osoby jako „nieosoby”. W związku z czym została nazywana emocją wojny (Levi 1987). Na podstawie studiów działań wojennych wyciągnięto wniosek, że pogarda musiała towarzyszyć nazistom, aby mogli podejmować działania eksterminacyjne wobec narodu żydowskiego w trakcie II wojny światowej. Z tym samym aspektem wiąże się fakt, że pogarda jest używana do sprawowania władzy (Kemper 1990). Jeżeli chodzi o konsekwencje odczuwania pogardy, to dowiedziono, że wyrażona wobec innej osoby jest silnym bodźcem wywołującym odczucie wstydu (Izard 1977). Co dość wyraźnie lokuje tę emocję w siatce społecznych zależności. Ponadto prowadzi do zachowań agresywnych, stanowiąc obok wstrętu i złości jeden z elementów tzw. triady wrogości (ang. CAD triad - contempt - anger - disgust, Baumeister, Smart, Boden 1996). To z kolei koresponduje z danymi, które mówią, że odczucie pogardy wobec partnera jest czynnikiem destrukcji w małżeństwie i predyktorem rozwodu (Gottman, Silver 1999). Pogarda jest także analizowana ze względu na swoje społecznie pozytywne funkcje. Jedną z nich jest mobilizowanie energii i utrzymywanie jej na wysokim poziomie, przez co trenerzy sportów kontaktowych indukują ją obok złości u swoich zawodników (Izard, Ackerman 2005). Stąd być może częstsza ekspresja pogardy przez mężczyzn (Stapley, Haviland 1989), którzy w większym stopniu są fanami tego typu dyscyplin sportowych niż kobiety. Kolejnym pozytywną funkcją pogardy jest scalenie grupy własnej (Tran 2004).

Reasumując, pogarda jest uznawana za negatywną emocję antagonistyczną, wysoce kontrolowaną, wynikającą z poczucia wyższości wobec innej osoby lub grupy osób (Gaunt, Leyens, Demoulin 2002). Stanowi element konstytucyjny tzw. triady wrogości. Prowadzi pośrednio do agresji lub odrzucenia. Jej aspektem pozytywnym jest podtrzymanie spójności w grupie, natomiast aspektem negatywnym są uprzedzenia wobec grupy obcej. Jednym z dowodów społecznego charakteru pogardy może być m.in. jej upowszechnienie w dyskursie publicznym. Uważa tak m.in. Michał Głowiński (2007), który aktualny dyskurs polityczny w Polsce nazywa retoryką nienawiści przeciwstawną retoryce empatii, która pozbawiona jest agresji i pogardy. Świadczyć może o tym między innymi wypowiedź Romana Giertycha, który w roku 2007, pełniąc funkcję Ministra Edukacji i uczestnicząc w Marszu dla Życia i Rodziny, wypowiedział się publicznie na temat uczestników warszawskiego Marszu Równości: „Ci wstrętni pederaści”. Za swoje zachowanie został listownie upomniany przez ówczesnego Rzecznika Praw Obywatelskich Jana Kochanowskiego ${ }^{1}$, który uznał wypowiedź Ministra za przejaw mowy nienawiści używanej w celu dyskryminacji jednostek lub grup społecznych i że posługiwanie się nią nie respektuje wymogu poszanowania godności przynależnej każdemu człowiekowi. Kolejnym dowodem jest zaprezentowany plakat wyborczy pochodzący z agresywnej kampanii PO z roku 2007. Na bilbordzie w jego centralnej części umieszczono na czarnym tle słowo ,pogarda”, a u dołu znajdował się przypis „Rządzi PiS, a Polakom wstyd”. Tak dobrane hasło reklamowe oddaje wspomnianą

\footnotetext{
${ }^{1}$ List dostępny na www.rpo.gov.p1/pliki/1180526741.pdf. [22.02.2015].
} 
wcześniej prawidłowość, mówiącą o tym, że w transakcjach interpersonalnych ekspresja pogardy wywołuje wstyd.

Opisane zjawisko koresponduje $\mathrm{z}$ modelem dyskursywnym znaczenia emocji (Strongman 2003: 292), zgodnie z którym przekaz zawarty w publicznych znakach, takich jak mowa emocjonalna, kształtuje życie społeczne. W podejściu tym dominuje koncentracja na pragmatyce emocji, czyli nie tylko na tym, o czym wypowiedź emocjonalna informuje, ale na tym, jak wpływa na codzienne życie społeczne, ponieważ

W życiu codziennym mówienie o emocjach często funkcjonuje jako komentarz moralny przekazujący — jeśli nie wprost, to przynajmniej implicite - ocenę tego, jak pożądane są omawiane działania oraz ich konsekwencje dla Ja i społeczeństwa. Mówienie o takich, a nie innych uczuciach w określonym kontekście to mówienie o skłonnościach do myślenia lub działania w taki, a nie inny sposób (White 2005: 65).

\section{BADANIA WLASNE}

\section{Problem badawczy}

Podstawowym celem prezentowanego badania było wyłonienie zbioru prototypowych cech reprezentacji pogardy i poznanie ich wewnętrznej organizacji. W związku z czym sformułowano trzy pytania badawcze:

1. Czy reprezentacja pogardy posiada strukturę prototypową i jakie elementy wchodzą w zakres prototypu?

2. Czy zachodzi ,potencjalna synteza”, czyli udział emocji podstawowych, w konstytucji reprezentacji pogardy?

3. Czy w konstytucji reprezentacji pogardy występują obok pogardy inne emocje tworzące „triadę wrogości” — wstręt i złość?

\section{Organizacja i przebieg badania}

W badaniu wzięło udział 136 ochotników, w tym 91 kobiet i 45 mężczyzn, w wieku od 20 do 50 lat. Badani zostali poproszeni o opisanie wspomnienia autobiograficznego sytuacji, w której przeżywali pogardę. Instrukcja opisu ${ }^{2}$, przekazana badanym, pochodziła z oryginalnych badań Shavera i współpracowników (1987) i była wcześniej wykorzystywana w innych badaniach emocji złożonych (Jasielska 2010, 2012). Jedyną modyfi-

\footnotetext{
${ }^{2}$ Instrukcja: Pomyśl o realnej sytuacji z Twojego życia, w której odczuwałeś/łaś pogardę.

Spróbuj przez chwilę przypomnieć sobie tyle detali tej sytuacji ile możliwe, a następnie opisz to odczucie:

Napisz dokładnie, co spowodowało to uczucie.

Napisz jak najwięcej detali, ile potrafisz dotyczących tego co:

Odczuwałeś/łaś i myślałeś/łaś w tej sytuacji.

Jeśli mówiłeś/łaś, to co i w jaki sposób?

Jakie zmiany zaszły w twoim ciele?

Co robiłeś/łaś, jak się zachowywałeś/łaś?

Jak długo trwało to odczucie? Jak się zmieniało? Co było przyczyną zmiany lub ustąpienia tego uczucia?

Czy możesz dodać jeszcze coś, co pomoże opisać ten epizod emocjonalny w pełni?
} 
kacją wprowadzoną do instrukcji była prośba o opisanie czasu trwania emocji. Wcześniejsze badania oraz specyfika pogardy sugerowały, że cecha ta może być krytyczna dla reprezentacji tej emocji.

Do oceny uzyskanych wspomnień zrekrutowano trzech sędziów kompetentnych, którzy nie znali celu badania. Wszyscy byli psychologami specjalizującymi się w dziedzinie emocji. Sędziowie otrzymali listę potencjalnych $47 \mathrm{cech}$ pogardy sporządzoną na podstawie literatury przedmiotu (m.in. Ben-Ze'ev 2000; Tran 2004). Ich zadanie polegało na oszacowaniu, czy dana cecha jest obecna w narracji czy nie. Przyjęto, że jeżeli przynajmniej dwóch sędziów stwierdziło, że dana cecha jest obecna, to cecha ta zostanie uznana za występującą w narracji. Zgodność między sędziami była zadowalająca. Zgodnie z kryterium prototypowości obecnym $\mathrm{w}$ literaturze przedmiotu za prototypowe uznano te cechy, które pojawiły się w 20\% narracji (Cantor, Mischel 1993; Horowitz, Wright, Lowenstein, Parad 1981; Jasielska 2010; Shaver i in. 1987).

\section{Wyniki}

Średnia ilość cech tworzących prototyp pogardy wyniosła $\mathrm{M}=10,72(\mathrm{SD}=3,62)$. Minimalna ilość cech zawartych w opisie wyniosła 1, przy czym w ogóle warto się zastanowić, czy badana osoba faktycznie dotarła do wspomnienia autobiograficznego, w którym identyfikowała emocję kryterialną. Maksymalna ilość cech to 19.

Na podstawie analizy treści poszczególnych cech wyłoniono pięć zasadniczych elementów konstytuujących prototypową reprezentację pogardy. Są to: przyczyna, subiektywne przeżycie, zachowanie, regulacja i charakterystyka czasowa. Specyfikację tych elementów wraz z częstotliwością występowania przedstawia tabela 1 .

Tab. 1. Cechy prototypu pogardy

\begin{tabular}{lll}
\hline udział & \multicolumn{1}{c}{ cechy prototypowe pogardy } & \multicolumn{1}{c}{ kategorie cech } \\
\hline $86 \%$ & dewaluacja innej osoby (zachowania innej osoby) & \\
$52 \%$ & cudze zachowanie aspołeczne, amoralne, aetyczne & \\
$34 \%$ & przekraczanie norm społecznych & przyczyna \\
$30 \%$ & dostrzeganie cudzego braku wartości & \\
$27 \%$ & zmiana oceny osoby z pozytywnej na negatywną & \\
\hline $58 \%$ & odczucie złości & odczucia \\
$55 \%$ & nieprzyjemne doznania & \\
$46 \%$ & odczuwanie pobudzenia & zachowanie \\
$43 \%$ & odczucie wstrętu & \\
\hline $35 \%$ & interpersonalne odrzucenie & regulacja \\
$25 \%$ & zaniechanie relacji & temporalność \\
\hline $39 \%$ & dystansowanie się & \\
$25 \%$ & wycofanie się z sytuacji & \\
\hline $36 \%$ & $36 \%$ uczucie minęło & \\
$31 \%$ & $31 \%$ uczcie trwa &
\end{tabular}




\section{Wnioski}

Istnieje prototypowa specyficzna postać reprezentacji pogardy. Podobnie jak w większości prototypów emocji w uzyskanym prototypie pogardy zidentyfikowano powszechne elementy, takie jak przyczyna, akty behawioralne czy subiektywne odczucia. Podobnie jak inne prototypy emocji złożonych (np. wstyd, Jasielska 2012, czy duma, Jasielska 2010) prototyp pogardy jest uboższy w elementy w porównaniu do prototypów emocji podstawowych (np. radości, Jasielska 2013, czy smutku, Jasielska 2011). Taki stan rzeczy jest potwierdzeniem mniejszej uniwersalności emocji złożonych i większego udziału doświadczeń idiosynkratycznych w reprezentowaniu tych emocji. Ponadto prototypowa pogarda $\mathrm{w}$ ujęciu potocznym jest pojmowana jako emocja obdarzona walencją negatywną. Stanowisko teoretyczne, które sugeruje pozytywną funkcję emocji, rozumianą np. jako scalenie grupy własnej (Tran 2004), pozostaje na razie czysto naukowym odkryciem (por. Beedie, Terry, Lane 2005). Dowodem jest wyłoniona struktura prototypu, w której pojawia się aspekt regulacji emocji, charakterystyczny dla prototypu emocji negatywnych (por. smutek, Jasielska 2011, czy wstyd, Jasielska 2012; Shaver i in. 1987) i odzwierciedlający powszechny, hedonistyczny kierunek regulacji emocjonalnej (Wojciszke 2003).

Obecność emocji podstawowych - złości i wstrętu w prototypie pogardy umacnia „potencjalną syntezę”, czyli koncepcję zakładającą obecność atrybutów emocji podstawowych w emocjach złożonych (Johnson-Laird, Oatley 2005: 580). Współwystępowanie tych właśnie emocji potwierdza istnienie tzw. „diady wtórnej” w emocjach złożonych. „Diadą wtórną” nazywane są emocje oddalone na plutchikowskim kole emocji o jedno pole (Plutchik 2002). Kołowy diagram zaproponowany przez autora umożliwia uporządkowanie wszystkich emocji, a jego zrąb tworzą emocje podstawowe, które odpowiednio ze sobą zmieszane tworzą emocje wtórne. Jedną z obecnych na kole emocji wtórnych jest pogarda ,złożona“ ze wstrętu i złości (Turner, Stets 2009: 32). Dane z badania pokazują, że prawie połowie sytuacji pogardzie towarzyszy wstręt i/lub złość. Koincydencja tych emocji potwierdza „triadę wrogości”, czyli wzorzec emocjonalny, którego obecność zwiększa prawdopodobieństwo wystąpienia zachowań agresywnych i wrogich wobec innych (Izard, Ackerman 2005: 335; Rozin, Lowery, Imada, Haidt 1999). Kiedy do tych elementów doda się obecne w prototypie pobudzenie, to wyraźnie widać, że pogarda może być uznana za emocję towarzyszącą tzw. „złości gorącej” utożsamianej ze wściekłością w przeciwieństwie do „złości zimnej” utożsamianej z irytacją (Banse, Scherer 1996). Kiedy spojrzy się na te elementy całościowo, to można w nich odnaleźć atrybuty ,nienawiści gorącej”, w której przeważa agresja i złość, oraz „nienawiści gniewnej”, której towarzyszy intencja zniszczenia (Sternberg 2005).

Szczególnie kontrowersyjna w prototypie jest polaryzacja dotycząca trwania pogardy. Blisko jedna trzecia osób badanych rozumie pogardę jako stan w krótkiej perspektywie czasowej, jako emocję chwilową. Zbliżona liczba osób pojmuje pogardę pod postacią postawy czy ustosunkowania (lub cechy?), ujmowanych w długiej perspektywie czasowej. 


\section{PODSUMOWANIE}

W badaniu uzyskano dostęp do prototypu pogardy poprzez analizę narracji. I choć metoda ta ma przewagę nad innymi badaniami prototypu emocji (np. semi-strukturalizowane wywiady na temat najbardziej typowych komponentów emocji, Lindsay-Hartz, deRivera, Mascolo 1995), ponieważ opiera się na konkretnym i rzeczywistym wspomnieniu autobiograficznym (Feldman Barrett, Fossum 2001; Kroska, Goldstone 1996), to posiada także swoje ograniczenia. Uzyskanie w pełni spontanicznych, wystarczająco rozbudowanych narracji na temat pogardy i w ogóle emocji złożonych bez dodatkowych sugestii jest praktycznie niemożliwe (Shaver i in. 1987; Tangney, Dearing 2002: 49). Empiryczna powtarzalności tego stanu rzeczy podważa ogólne założenia mówiącej o narracyjnej formie reprezentacji emocji. Ponadto choć wykorzystano w badaniu narrację, to w żaden sposób nie wykorzystano „narracyjnej wątkowości”. Ocena narracji dokonywana przez sędziów, polegająca na identyfikowaniu cech, nie dostarczyła informacji o cesze kryterialnej dla tej formy reprezentacji, czyli wątku. Koncentracja na obecności pewnych cech, przy braku informacji na temat organizacji czasowej, dostarcza niestety danych fragmentarycznych. Chcąc uniknąć tej słabości metodologicznej w przyszłości, należałoby objąć analizą aspekt syntaktyczny stworzonych autonarracji, oceniając na przykład udział wypowiedzi o charakterze mowy wiązanej w stosunku do wypowiedzi o charakterze mowy skandowanej.

Przeprowadzone badania choć zostały zainicjowane w obszarze psychologii emocji i psychologii poznawczej, to w niewielkim stopniu koncentrują się na przeżyciu emocjonalnym człowieka i dostarczają czegoś na podobieństwo ,językowego obrazu świata" obecnego w studiach językoznawczych (Szumska 2000). Z drugiej jednak strony wyniki dostarczyły niezwykle istotnego z punktu widzenia oddziaływań korekcyjnych (np. psychoterapeutycznych) wglądu w istotę omawianego zjawiska, pokazując różnicę pomiędzy ulotnością a trwałością przeżywania pogardy. Co z kolei można interpretować jako pośrednie potwierdzenie ,retoryki nienawiści” obecnej w polskim społeczeństwie.

$\mathrm{W}$ dalszych penetracjach empirycznych można dokonać np. analizy różnic w strukturze prototypu u osób o bogatym i ubogim stylu konwersacji (Stein, Trabass, Liwag 2005) czy poziomem emocjonalnej fluencji werbalnej (Szepietowska, Gawda 2011). Koncentrując zaś badania w obszarze różnic indywidualnych, można podjąć temat zależności pomiędzy organizacją reprezentacji pogardy a skłonnością do podejmowania zachowań agresywnych czy podatnością na zawstydzanie (ang. shame-proneness) (Tangney, Dearing 2002).

\section{BIBLIOGRAFIA}

B a ume is ter R.F., S mart L., B oden J. 1996: Relation of threatened egotism to violence and agression: the dark side of high self-esteem, Psychological Review 103, 5-33.

Beedie Ch.J., Terry P.C., Lane A.M. 2005: Distinctions between emotion and mood, Cognition and Emotion 19, 847-878. 
B a n s e R., S cherer K. 1996: Acoustic profiles in vocal emotion expression, Journal of Personality and Social Psychology 70 (3), 614-636.

B en-Ze'ev A. 2000: The subtlety of emotions, Cambridge: A Bradford Book-The MIT Press.

Cantor N., Mischel W. 1993: Prototypy w spostrzeganiu osób, [w:] T. Maruszewski (red.), Poznanie - afekt - zachowanie, Warszawa: PWN, 20-52.

D a nie luk B. 2013: Ile jest Ja w emocjach samoświadomościowych? Rodzaj zaangażowania Ja a wstyd, poczucie winy i zakłopotanie, Psychologia Społeczna 26, 302-322.

D u s za k A. 2003: O emocjach bez emocji. Gniew w perspektywie lingwistycznej, [w:] A. Duszak, N. Pawlak (red.), Anatomia gniewu. Emocje negatywne w językach i kulturach świata, Warszawa: Wydawnictwo UW, 13-23.

E k m an P. 1992: An argument for basic emotions, Cognition and Emotion 6, 169-200.

F ehr B. 2007: Prototypowe podejście do badania miłości, [w:] R.J. Sternberg, K. Weis (red.), Nowa psychologia emocji, Taszów: Moderator, 331-360.

Fehr B., Russel1 J.A. 1984: Concept of emotion viewed from a prototype perspective, Journal of Experimental Psychology: General 113, 464-486.

Feldman Barrett L., Fossum T. 2001: Mental representations of affect knowledge, Cognition and Emotion 15, 333-363.

F is cher A.H., Manste a d A.S.R. 2008: Social functions of emotion, [w:] M. Lewis, J. Haviland-Jones, L. Feldman Barrett (red.), Handbook of Emotions, $3^{\text {rd }}$ ed., New York: Guilford, 456-468.

F is cher A.H., Manstead A.S. R., Mosquer a P.M.R. 1999: The role of honour-related vs. individualistic values in conceptualising pride, shame, and anger: Spanish and Dutch cultural prototypes, Cognition and Emotion 13, 149-179.

Fitne s s J., F1etcher G.J. 1993: Love, hate, anger, and jealousy in close relationships: A prototype and cognitive appraisal analysis, Journal of Personality and Social Psychology 65, 942-958.

Gaunt R., Leyens J.-P., D emoulin S. 2002: Intergroup relations and the attribution of emotions: Controllability of memory for secondary emotions associated to ingroup versus outgroup, Journal of Experimental Social Psychology 38, 508-551.

G a w da B. 2007: Ekspresja pojęć afektywnych w narracjach osób z osobowościa antyspołeczna, Lublin: Wydawnictwo UMCS.

G aw da B. 2011: Skrypty miłości, nienawiści i lęku u osób antyspołecznych, Warszawa: Difin.

Głowińs ki M. 2007: Retoryka nienawiści, Nauka 2, 19-27.

G o t t m a n J., Silver N. 1999: The Seven Principles for Making Marriage Work, New York: Three Rivers Press.

Hog a n P.C. 2003: The Mind and Its Sories. Narrative Universals and Human Emotion, Cambridge: Cambridge University Press.

Horowitz L.M., Wright J.C., Lowenste in E., Parad H.W. 1981: The prototype as a construct in abnormal psychology: 1. A method for deriving prototypes, Journal of Abnormal Psychology 90, 568-574.

I zard C.E. 1977: Human emotions, New York: Plenum Press.

I zard C.E., A ckerm an B.P. 2005: Motywacyjne, organizacyjne i regulujące funkcje odrębnych emocji, [w:] M. Lewis, J.M. Haviland-Jones (red.), Psychologia emocji, Gdańsk: GWP, 327-341.

J a s i els k a A. 2010: Analiza narracji jako źródło wiedzy o emocjach — prezentacja metody, [w:] M. StraśRomanowska, B. Bartosz, A. Żurko (red.), Badania narracyjne w psychologii, Warszawa: Eneteia Wydawnictwo Psychologii i Kultury, 181-202.

Jasie1ska A. 2011: „Nie ma radości bez smutku” - porównanie reprezentacji emocji podstawowych, Czasopismo Psychologiczne 17, 161-176.

J a siels k a A. 2012: Treść i struktura prototypu wstydu jako przykładu emocji złożonej, Roczniki Psychologiczne 15, 101-107.

Jasielska A. 2013: Charakterystyka i konsekwencje potocznego rozumienia emocji, Poznań: Wydawnictwo Naukowe UAM. 
John s o n-La ird P.N., O atley K. 2005: Poznawcza i społeczna konstrukcja w emocjach, [w:] M. Lewis, J.M. Haviland-Jones (red.), Psychologia emocji, Gdańsk: GWP, 576-597.

Kemper T.D. 1990: Social relations and emotions: A structural approach, [w:] T.D. Kemper (red.), Research agendas in the sociology of emotions, Albany, NY: State University of New York University Press, 207-236.

Kövecses Z. 2000: Metaphor and emotion: language, culture, and body in human feeling, Cambridge: Cambridge University Press.

Kroska A., Goldstone R.L. 1996: Dissociations in the similarity and categorizations of emotions, Cognition and Emotion 101, 27-45.

Lew iński P. 2006: Operatory emocji, [w:] K. Michalewski (red.), Wyrażanie emocji, Łódź: Wydawnictwo Uniwersytetu Łódzkiego, 51-61.

Levi P. 1987: If this is a man, London: Sphere.

Lindsay-Hartz J., deRivera J., Mascolo M. 1995: Differentiating guilt and shame and their effects on motivation, [w:] J.P. Tangney, K.W. Fisher (red.): Self-conscious emotions: Pride, shame, guilt and embarrassment, New York: Guilford, 274-300.

Malc ze w s k i J. 1985: Szkolny stownik terminów nauki o języku, Warszawa: Wydawnictwa Szkolne i Pedagogiczne.

Marczewska-Okuniewska W., Kurcz I. 2003: Asymetria pozytywno-negatywna w psychologii i psycholingwistyce, [w:] A. Duszak, N. Pawlak (red.), Anatomia gniewu. Emocje negatywne w jezykach i kulturach świata, Warszawa: Wydawnictwo UW, 25 Stownik terminów nauki o języku 37.

Maruszewski T., Ścigała E. 1998: Emocje - aleksytymia - poznanie, Poznań: Wydawnictwo Humaniora.

Mikoła j czuk A. 2006: O wyrażaniu i komunikowaniu uczuć w języku polskim (na przykładzie radości), [w:] K. Michalewski (red.), Wyrażanie emocji, Łódź: Wydawnictwo Uniwersytetu Łódzkiego, 84-93.

$\mathrm{Nabi}$ R.L. 2002: The theoretical versus the lay meaning of disgust: Implications for emotion research, Cognition and Emotion 16, 695-703.

Najsłynniejsze hasła 2011, [w:] wirtualnapolska.pl, 14.09.2011, <http://wiadomosci.wp.pl/gid,13728698, gpage,6,img,13728876,kat,1342,title,Najslynniejsze-hasla,galeria.html $>$ [22.02.2015].

Nęcka E., Orzechowski J., Szymura B. 2006: Psychologia poznawcza, Warszawa: Academica.

Now a kow sk - Ke m p n I. 2000: Konceptualizacja uczuć w języku polskim. Część II. Data, Warszawa: Wydawnictwo Wyższej Szkoły Pedagogicznej.

Pankalla A., Grońska-Turunen J. 2010: Sisu-fińska emocja kulturowa i jej mitoanaliza w koncepcji R. Shwedera, Roczniki Psychologiczne 13, 29-53.

Panks epp J. 2005: Emocje jako twory naturalne w mózgu ssaków, [w:] M. Lewis, J.M. Haviland-Jones (red.), Psychologia emocji, Gdańsk: GWP, 185-209.

Plu tchik R. 2002: Emotions and life: Perspectives from psychology, biology, and evolution, Washington, DC: American Psychological Association.

R o s c h E.H. 2006: Zasady kategoryzacji, [w:] Z. Chlewiński (red.), Psychologia poznawcza w trzech ostatnich dekadach, Gdańsk: GWP, 409-430.

Rozin P., Low ery L., Im a d a S., Haid t J. 1999: The CAD triad hypothesis: A mapping between three moral emotions (contempt, anger, disgust) and three moral codes (community, autonomy, divinity), Journal of Personality and Social Psychology 75, 574-585.

R u s se11 J.A. 1991: In defense of a prototype approach to emotion concepts, Journal of Personality and Social Psychology 60, 37-47.

Russell J.A., Fehr B. 1994: Fuzzy concepts in a fuzzy hierarchy: Varieties of anger, Journal of Personality and Social Psychology 67, 186-205.

Russel1 J.A., Lemay G. 2005: Pojęcia dotyczące emocji, [w:] M. Lewis, J.M. Haviland-Jones (red.), Psychologia emocji, Gdańsk: GWP, 617-633.

S a a r n i C. 1999: The development of emotional competence, New York: Guilford Press. 
Shaver P., Schwartz J., Kirs on D., O' Connor C. 1987: Emotion knowledge: Further exploration of a prototype approach, Journal of Personality and Social Psychology 52, 1061-1086.

Shweder R.A. 1998: „Nie jesteś chory tylko się zakochałeś” — emocja jako system interpretacji, [w:] P. Ekman, R.J. Davidson (red.), Natura emocji, Gdańsk: GWP, 36-47.

Shwe der R.A., H aidt J. 2005: Psychologia kulturowa emocji — od starożytności po czasy współczesne, [w:] M. Lewis, J.M. Haviland-Jones (red.), Psychologia emocji, Gdańsk: GWP, 504-524.

S i e m e r M. 2008: Beyond prototypes and classical definitions: Evidence for a theory-based representation of emotion concepts, Cognition and Emotion 22, 620-632.

Stapley J.C., Haviland J.M. 1989: Beyond depression: Gender differences in normal adolescents' emotional expierience, Sex Roles 20, 295-308.

S te in N.L., Trabas so T., Liw ag M.D. 2005: Rozumienie emocji w teorii oceny — implikacje dla rozwoju i uczenia się, [w:] M. Lewis, J.M. Haviland-Jones (red.), Psychologia emocji, Gdańsk: GWP, 550-575.

S tern berg R.J. 2005: Understanding and combation hate, [w:] Sternberg R.J. (red.), Psychology of hate, Washington: APA, 37-50.

S tro ng m a n K.T. 2003: The Psychology of Emotion: From Everyday Life to Theory, West Sussex: John Wiley \& Sons Ltd.

Szepietowska E.M., Gawda B. 2011: Ścieżkami fluencji werbalnej, Lublin: Wydawnictwo UMCS. S zums k a D. 2000: O emocjach bez emocji, Język a kultura 14, 199-208.

Tang ne y J.P., D e aring R.L. 2002: Shame and guilt, New York: The Guilford Press.

Tr a n V. 2004: The influence of emotions on decision-making processes in management teams, Praca doktorska, Universytet w Genewie.

Trze bińs k i J. (red.) 2002: Narracja, jako sposób rozumienia świata, Gdańsk: GWP.

Turn er J. H., Stets J.E. 2009: Socjologia emocji, Warszawa: Wydawnictwo Naukowe PWN.

Wa gn e r H.L. 2000: The accessibility of the term "contempt" and the meaning of the unilateral lip curl, Cognition and Emotion 14, 689-710.

W hite G.M. 2005: Reprezentacje znaczenia emocjonalnego: kategoria, metafora, schemat, dyskurs, [w:] M. Lewis, J.M. Haviland-Jones (red.), Psychologia emocji, Gdańsk: GWP, 53-71.

Wierzbicka A. 1999: Język - umyst - kultura, Warszawa: PWN.

Woj c i s zk e B. 2003: Skale regulacji nastroju, [w:] M. Marszał-Wiśniewska, T. Klonowicz, M. Fajkowska-Stanik (red.), Psychologia różnic indywidualnych, Gdańsk: GWP, 163-179.

\section{SUMMARY}

\section{Prototypical image of contempt in colloquial narratives}

Keyw ord s: emotion representation, narrative model of emotion, contempt, CAD triad, rhetoric of hate.

This study is based on the conclusion that emotion knowledge is organized in terms of prototypes and narratives. The subject of this exploratory study is a social post-cognitive complex emotion - contempt. The participants $(\mathrm{N}=136)$ were asked to describe an emotional autobiographical emotional episode. Then the subjects' narratives were categorized by coders. The result was a prototypical description of contempt. Derived, exploratory results provide mainly: 1) the description of complex emotion as prototype, 2) the structural characteristic of contempt, 3) nonspecific ,potential synthesis" in the field of postcognitive emotions and (4) specific CAD triad. 